\title{
Study of external parasitic infection in domestic dogs referred to Mazandaran veterinary clinic (Northern Iran)
}

\author{
Vahedi Nouri $\mathrm{N}^{*}$, Salehi $\mathrm{A}^{2}$, Masoumi $\mathrm{M}^{2}$ and Mohsen $\mathrm{A}^{2}$ \\ ${ }^{1}$ Razi Vaccine and Serum Research Institute, Agricultural Research, Education and Extension Organization (AREEO), Karaj, Iran \\ ${ }^{2}$ Veterinary Medicine Student, Babol Islamic Azad University, Iran
}

\begin{abstract}
This study evaluates external parasites in domestic dogs referred to veterinary clinics of Mazandaran Province (Northern Iran). The results of this study show that 110 Dogs (36.6\%) infected with external parasites than among 52 Dogs (17.3\%) infected with Rhipicephalus bursa. 41 dogs (13.6\%) infected with Ctenocephalides canis and $17 \mathrm{dogs}(5.6 \%)$ infected with both of Rhipicephalus bursa and Ctenocephalides canis. Considering the importance of external parasitic infection in domestic animals and the issue of public health, necessity of hygiene, prevention and control of these factors are very important.
\end{abstract}

\section{Introduction}

External parasites are a various group of Arthropod that have adapted to live on the body of many vertebrates. They may be found permanently or temporarily on host's body and west. Mites are the second most important carrier pathogen in vertebrates after mosquitoes. While they feed from vertebral body as forced parasite, they transmit a wide range of pathogens, including Bacteria, Viruses, Rickettsia and Protozoa. Ticks are very important of public health, because they live not only in the outdoors, but also in the humans have searching for a better living environment. The importance of tick bites in human should be considered as a problem because those who have somehow removed tick from their body should be prepared for maximum 30 days for outbreak of any signs and disease-related symptoms from tick like skin lesions at the bite site or temperature above $38^{\circ}$.

Paleontological studies have also shown that fleas have been infecting humans and animals since ancient times. These arthropods also cause dermatitis and if the animal's immune system is weak, they will cause death.

The close relationship between animals and humans causes the reason of many common infection diseases. Dog is an animal that has lived with humans for over 10000 years. This animal, as a member of the dog family, has adopted physically and socially so it can live in human's condition. This can cause many common diseases including parasite. In the meantime, Arthropods and especially this species as carriers of many infection agents play an important role.

Mazandaran province with latitude from $46^{\prime} 35^{\circ}$ to $58^{\prime} 36^{\circ}$ north latitude and $21^{\prime} 50^{\circ}$ to $08^{\prime} 54^{\circ}$ east longitude, located in north of Iran. Because of special geographical conditions, it is susceptible to the spread of many internal and external parasite agents including ticks. In this regard, surveys by Vahedi et al. [1] on ruminants (Cattle- sheep and goats) in the province show that 13 species of hard ticks are active. Dogs are among the animals that can carry many external parasites. According to the facts that the study of the status, distribution and abundance of external parasites are essential requirements for assessing the rise factors of infections caused by ticks and human transmitted disease, this study was performed on dogs in some parts of Mazandaran province.

\section{Material and method}

The method of this study was cross-sectional descriptive. For this purpose, samples from 300 domestic dogs referred to private veterinary clinics in Mazandaran province (northern Iran) for treatment was taken. External parasite samples separated from the animal's body by force after anesthesia by ether. After that, the samples placed in Ethanol $70 \%$ and glycerin $5 \%$ and sent to the laboratory for diagnosis. Samples examined in the laboratory under a magnifying glass at 10x and then at $40 x$.

\section{Result}

All the samples examined in the laboratory. The results showed that all the isolated ticks belonged to Rhipicephalus bursa and all the isolated fleas belonged to the Ctenocephalides canis (Figures 1 and 2). The results also show that 110 dogs (6.36\%) infected with external parasites and between them, 52 dogs (3.17\%) infected by Rhipicephalus bursa. In addition, 41 dogs (6.13\%) infected by Ctenocephalides canis and 17 dogs (6.5\%) infected with both Rhipicephalus bursa and Ctenocephalides canis.

Overall 96 dogs (23\%) infected with Rhipicephalus bursa, 58 dogs (19.3\%) infected with Ctenocephalides canis and 17 dogs infected with both Rhipicephalus bursa and Ctenocephalides canis.

${ }^{\star}$ Correspondence to: Vahedi Nouri N, Assistant Professor, Razi Vaccine and Serum Research Institute, Agricultural Research, Education and Extension Organization (AREEO), Karaj, Iran, E-mail: nsvahedi@yahoo.com

Key words: infection, parasite, dogs, Mazandaran

Received: February 01, 2020; Accepted: February 12, 2020; Published: February 14,2020 


\section{Discussion}

External parasite is active throughout the world and in most of vertebrates. The results of this study show that two species of external parasites are active in the investigated dogs.

Generally, the rate of infection was $36.6 \%$, which the rate of Rhipicephalus bursa was (23\%) and rate of Ctenocephalides canis was (19.3\%) (Tables 1 and 2). Reminding the role and importance of external parasites, especially ticks and fleas in the transmission of protozoan and bacterial agents, this rate of infection is significant. In addition, in a study of homeless dogs in Mazandaran, Gilan and Qazvin provinces [2], overall $82.8 \%$ of the dogs infected with external parasites, which the rate of infection with fleas was $(77.5 \%)$ and rate of infection with ticks was $(6.8 \%)$.

The reason for the high infection rate in the study of Ebrahimzadeh et al. [2], compared to this study was that in their study, dogs were homeless. Also, studies on dogs in Erzurum region of Turkey [3], showed overall $(43.75 \%)$ infection of the studied dogs with external parasites which share of fleas infection was $(35.42 \%)$ and share of ticks

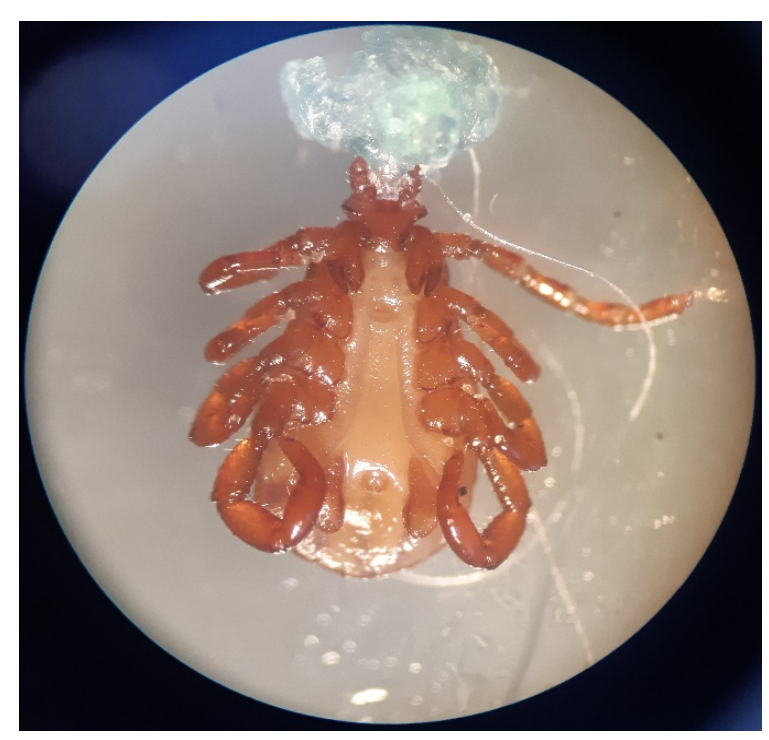

Figure 1. Rhipicephalus bursa

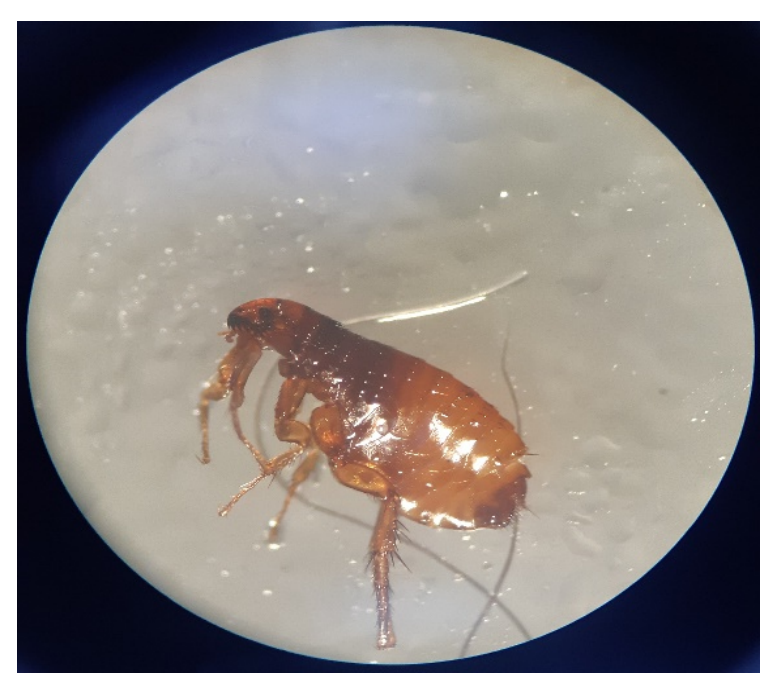

Figure 2. Ctenocephalides canis
Table 1. Number and percentage of Rhipicephalus bursa and Ctenocephalides canis infection in dogs reffered to north of Iran's clinics

\begin{tabular}{|c|c|c|c|c|}
\hline $\begin{array}{c}\text { Infection } \\
\text { status }\end{array}$ & Total & $\begin{array}{c}\text { Rhipicephalus } \\
\text { bursa }\end{array}$ & $\begin{array}{c}\text { Ctenocephalides } \\
\text { canis }\end{array}$ & $\begin{array}{c}\text { Rhipicephalus bursa + } \\
\text { Ctenocephalides canis }\end{array}$ \\
\hline Infected & $\begin{array}{c}110 \\
(36.6 \%)\end{array}$ & 52 & 41 & 17 \\
\hline $\begin{array}{c}\text { Non- } \\
\text { Infected }\end{array}$ & $\begin{array}{c}190 \\
(63.4 \%)\end{array}$ & 0 & 0 & 0 \\
\hline Total & $\begin{array}{c}300 \\
(100 \%)\end{array}$ & $52(17.3 \%)$ & $41(13.6 \%)$ & $17(5.6 \%)$ \\
\hline
\end{tabular}

Table 2. Number and percentage of Rhipicephalus bursa and Ctenocephalides canis infection in dogs referred to north of Iran's clinics

\begin{tabular}{|c|c|c|c|}
\hline Type of Infection & $\begin{array}{c}\text { Rhipicephalus } \\
\text { bursa }\end{array}$ & $\begin{array}{c}\text { Ctenocephalides } \\
\text { canis }\end{array}$ & Total \\
\hline Number & $69(23 \%)$ & $58(19.3 \%)$ & $300(100 \%)$ \\
\hline
\end{tabular}

infection was (6.25\%) and mite was (2.08\%) [4-8].

By Comparing two studies of Ebrahimzadeh and Aldemir with this study, concluded that flea contamination was higher than mite contamination. This may be due to sampling season that affect the activity of external parasite species. However, the geographical condition of the area should be considered.

As a conclusion, in this study, two species of external parasites identified and separated in dogs referred to veterinary clinics of Mazandaran province (north of Iran). It is advised that the prevention of external parasite's infection in domestic dogs should be considered based on hygienic actions such as spraying the environment and using anti- parasitic agents in pets.

\section{References}

1. Vahedi Noori N, Abdi Goodarzi M, Nejad Kiasari SM (2015) Evaluation of the species diversity and abundance of hard ticks (Family: Ixodidae) parasite of cattle and sheep in Mazandaran province. Vet $J$ 28: 58-64.

2. Ebrahimzade E, Fattahi R, Ahoo MB (2016) Ectoparasites of Stray Dogs in Mazandaran, Gilan and Qazvin Provinces, North and Center of Iran. J Arthropod Borne Dis 10: 364369. [Crossref]

3. Aldemir OS (2007) Epidemiological study of ectoparasites in dogs from Erzurum region in Turkey. Revue Méd Vét 158: 148-151.

4. González A, Castro Ddel C, González S (2004) Ectoparasitic species from Canis familiaris (Linné) in Buenos Aires province, Argentina. Vet Parasitol 120: 123-129. [Crossref]

5. Güçlü F (2002) Genel Parazitoloji, S.Univ. Basımevi. Konya.

6. Laamri M, El Kharrim K, Boukbal M, Belghyti D, Mrifag R (2012) 'Dynamique des populations de tiques parasites des bovins de la région du Gharb au Maroc', Revue d'Elevage et de Médecine Vétérinaire des Pays Tropicaux 65: 57-626.

7. Roupakias S, Mitsakou P, Nimer AA (2011) Tick removal. J Prev Med Hyg 52: 40-44. [Crossref]

8. Quintero MT, Gaxiola CS, Castillo MA, Juárez VG (2004) Algunas consideraciones sobre la presencia de garrapatas Rhipicephalus sanguineus (Acari Ixodidae) sobre perros y su repercusión en salud. Entomología Mexicana 3: 86-88.

Copyright: (C2020 Vahedi Nouri N. This is an open-access article distributed under the terms of the Creative Commons Attribution License, which permits unrestricted use, distribution, and reproduction in any medium, provided the original author and source are credited. 